\title{
Comparison of Severity Assessment Methods for Predicting Yield Loss to Rhizoctonia Foliar Blight in Soybean
}

\author{
K. C. Stetina, S. R. Stetina, and J. S. Russin, Department of Plant Pathology and Crop Physiology, Louisiana State \\ University Agricultural Center, Baton Rouge 70803
}

\begin{abstract}
Stetina, K. C., Stetina, S. R., and Russin, J. S. 2006. Comparison of severity assessment methods for predicting yield loss to Rhizoctonia foliar blight in soybean. Plant Dis. 90:39-43.

Rhizoctonia foliar blight, caused by Rhizoctonia solani Kühn anastomosis group 1, causes rapid and severe destruction of soybean foliage and pods during hot, wet weather. The objectives of this study were to determine the yield components affected by this disease and whether rating pod damage or foliar damage provides a more reliable method of assessing disease severity relative to impact on yield. Disease severity in the moderately resistant cv. NK S57-11 and the susceptible cv. Buckshot 723 was assessed in field plots in 1996 and 1997 using foliar and pod ratings (0-to-10 scale corresponding to 0 to $100 \%$ of tissue affected). Based on results from regression analysis, pod number, seed number, and seed weight per plot decreased as disease severity increased, whereas the proportion of partially filled pods and the weight of 100 seed were not affected. Yield loss appeared to be due primarily to loss of entire pods. Foliar and pod assessments of disease severity correlated positively in $1996(r=0.8343)$ and $1997(r=0.5958)$ for both cultivars, which suggests that either method can be used to identify relative differences among cultivars. However, pod assessments accounted for more variability than foliar assessments under low-disease conditions. Plants exhibiting moderate to severe symptoms of Rhizoctonia foliar blight also retained green stems and pods at harvest, which was evidence of delayed maturity.
\end{abstract}

Additional keywords: aerial blight, disease assessment, web blight

Rhizoctonia foliar blight, caused by Rhizoctonia solani Kühn anastomosis group 1, was first reported in Louisiana in 1954 by Atkins and Lewis (3). It is a serious disease that causes a rapid and severe destruction of soybean (Glycine max (L.)

Corresponding author: S. R. Stetina

E-mail: sstetina@msa-stoneville.ars.usda.gov

Current address of K. C. Stetina: United States Department of Agriculture-Agricultural Research Service (USDA-ARS) Southern Weed Science Research Unit, PO Box 350, Stoneville, MS 38776.

Current address of S. R. Stetina: USDA-ARS Crop Genetics and Production Research Unit, PO Box 345, Stoneville, MS 38776.

Current address of J. S. Russin: College of Agricultural Sciences, Southern Illinois University, Carbondale 62901

Approved for publication by the Director of the Louisiana Agricultural Experiment Station as manuscript number 04-38-0415.

Mention of trade names or commercial products in this article is solely for the purpose of providing specific information and does not imply recommendation or endorsement by the USDA.

Accepted for publication 10 July 2005 .

\section{DOI: 10.1094/PD-90-0039}

This article is in the public domain and not copyrightable. It may be freely reprinted with customary crediting of the source. The American Phytopathological Society, 2006.
Merr.) foliage and pods during hot, wet weather. The disease caused estimated soybean yield losses of 42,400 and 24,800 metric tons in Louisiana in 1996 and 1997, respectively (28). These amounts are approximately $30 \%$ (1996) and 14\% (1997) of soybean yield lost to pathogens in Louisiana.

There are two stages of Rhizoctonia foliar blight development. The first is the soilborne phase, when disease foci become established. The primary inoculum for Rhizoctonia foliar blight consists of sclerotia or mycelial fragments that are splashed onto the plant by rain $(23,30)$. From these initial infections, mycelium grows along the plant surface, eventually reaching upper portions of the plant. The second phase of the disease is the foliar phase, wherein the fungus will spread from diseased to healthy plants throughout the canopy by means of mycelial bridges $(23,30)$. During this phase, disease foci enlarge along and across rows, often coalescing to form large areas of diseased plants.

Several factors are critical for initiation and spread of Rhizoctonia foliar blight. Availability of free moisture influences disease incidence and severity. In dry periods, severity is markedly lower and foci are smaller compared with wet periods (29). Crop canopy density influences spread of the pathogen from plant to plant $(16,29)$. A dense crop canopy allows for more foliar contact and increased humidity, which promote mycelial bridging (29). Rainfall during flowering and early pod development (R3) (9) enhances disease severity. The fungus can infect flowers and kill pods before they fully develop (30).

Evaluation of resistance to Rhizoctonia foliar blight in soybean cultivars has been based primarily on severity of foliar symptoms $(4,13)$. Because flowers and pods also can be affected, it is possible that damage to these tissues in the lower portion of the soybean canopy may be masked by apparently healthy foliage at the top of the canopy. Such assessment could allow advancement of breeding lines with apparently healthy foliage even when flowers or pods have been damaged by $R$. solani.

The current study addressed two main objectives. The first objective was to determine which yield components were affected most severely by the disease. A second objective was to determine whether assessing the impact of Rhizoctonia foliar blight on pods provides a more accurate and reliable method of screening soybean genotypes for disease resistance than foliar ratings. A preliminary report has been published (25).

\section{MATERIALS AND METHODS}

The study was conducted in 1996 and 1997 at the Louisiana State University Agricultural Center Rice Research Station, Crowley, LA. The test site had a history of Rhizoctonia foliar blight. Disease developed during both years from natural inoculum. Rainfall and temperature data were collected from the automated weather station at Crowley, LA.

Soybean cvs. NK S57-11 (maturity group V) and Buckshot 723 (maturity group VII) were planted on a $0.76-\mathrm{m}$ row spacing in an area approximately $25 \mathrm{~m}$ wide and $20 \mathrm{~m}$ long. NK S57-11 is moderately resistant to Rhizoctonia foliar blight whereas Buckshot 723 is susceptible (27). Planting dates were 6 June 1996 and 12 May 1997.

When plants reached the late R5 growth stage, the entire area planted to each cultivar was examined to find sections of row with defined levels of disease severity. Plots consisting of sections of row with uniform Rhizoctonia foliar blight severity were established. Severity within each plot was assessed on a 0-to-10 scale, where 0 indicated no disease and 1 to 10 represented amounts of foliage affected in $10 \%$ 
increments (i.e., $1=1$ to $10 \%$ of the foliage blighted or lost, $2=11$ to $20 \%$ of the foliage affected, and so on). Season-long rainfall was greater in 1996 than in 1997, which resulted in disease foci that differed in size among years. Consequently, plots were $0.50 \mathrm{~m}$ in length in 1996 and $0.25 \mathrm{~m}$ in length in 1997. Within each year, plots were uniform with respect to plant number (approximately 12 plants per plot in 1996 and 6 plants per plot in 1997). The presence of $R$. solani in each selected plot was confirmed based on microscopic examination of the fungus recovered from infected tissue. The number of plots evaluated each year depended upon the frequency of plots showing the various severity classes. In 1996, 31 plots of each soybean cultivar were selected to represent the range in disease severity during that growing season. Due to lower disease pressure in 1997 , 26 plots were selected for NK S57-11 and 25 plots were selected for Buckshot 723 . Immediately after foliage was rated, severity was rated on pods in each plot using the same 0 -to- 10 severity scale, where 0 indicated no disease and 1 to 10 represented amounts of pods blighted or aborted in $10 \%$ increments. Aborted pods could be seen on the ground or on foliage in the lower portions of the canopy.

Plants were removed from each plot when they reached maturity (R8) by cutting through the stems just above the soil line. Harvested plants were dried for 7 days on greenhouse benches. Ambient temperatures in the greenhouse during this period ranged from 21 to $32^{\circ} \mathrm{C}$. Pods and seed were removed by hand. Number of pods, total number of seed, and total seed weight (in grams) were recorded for each plot. To determine the mechanism or mechanisms by which Rhizoctonia foliar blight causes yield loss, the numbers of full and partially filled pods and the weight of 100 seed (in grams) also were determined. Data on seed moisture were not collected because of insufficient seed volume; it was assumed that moisture was uniform within each cultivar because of the duration plants were dried in the greenhouse.

Differences in disease severity and plot size between 1996 and 1997 required data from each year to be analyzed independently. Simple linear regression $(P \leq 0.05)$ was performed using SAS JMP (SAS Institute, Cary, NC) to determine the impact of Rhizoctonia foliar blight severity on yield components (12). The relationship between foliar and pod assessments of disease severity was examined using simple linear correlation analysis $(P \leq 0.05)$ (SAS JMP; SAS Institute) to determine whether one method was more reliable for disease assessment (12).

\section{RESULTS AND DISCUSSION}

Rhizoctonia foliar blight became more widespread and severe in 1996 than 1997 following more favorable environmental conditions. Rainfall between years was comparable in sum but different in pattern. There was more rain late in the season in 1996, whereas there was more rain early in the season in 1997 (Fig. 1). Both rainfall patterns occur commonly in Louisiana. Due to the late-season rainfall in 1996, disease foci were larger in area and more numerous in 1996 than in 1997. Foliar disease severity in plots at the late R5 growth stage ranged from 1.0 to 8.0 in 1996 and from 0 to 3.0 in 1997. Ratings for pod disease severity at that time were

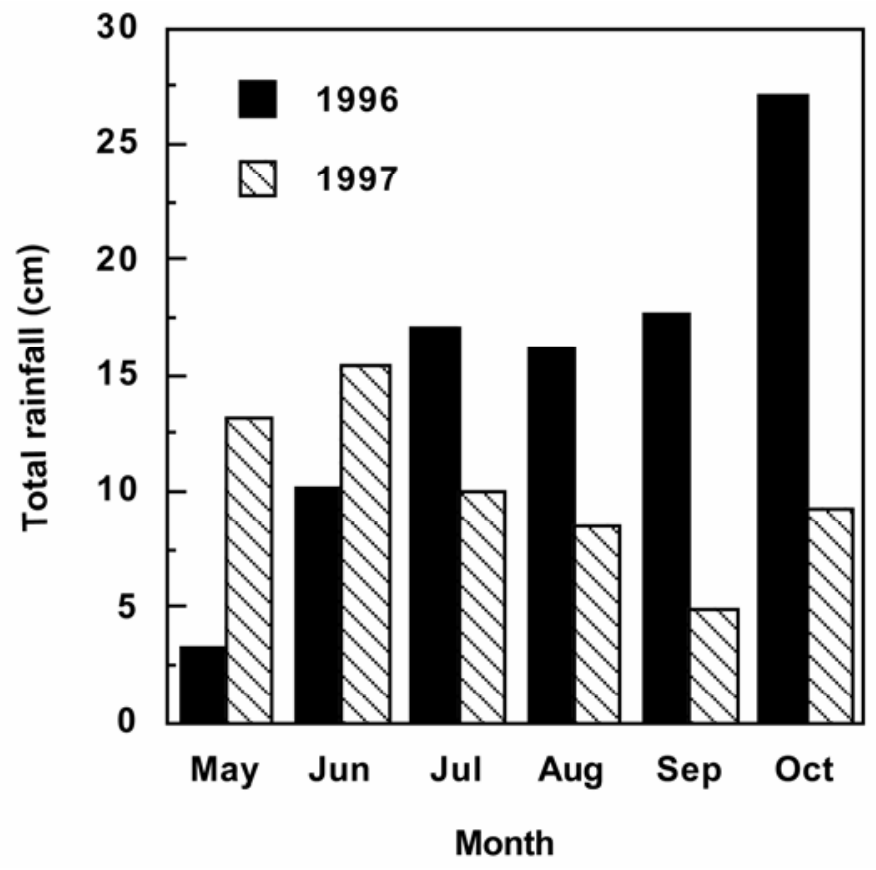

Fig. 1. Rainfall during the soybean growing season in 1996 and 1997 in Crowley, LA. more similar across the 2 years, ranging from 1.0 to 8.0 in 1996 and from 0 to 7.5 in 1997. This may be due to a more uniform, humid microclimate within the crop canopy late in the season. Mean monthly temperatures were similar in both years, ranging from 20.7 to $28.0^{\circ} \mathrm{C}$ in 1996 and from 20.9 to $28.7^{\circ} \mathrm{C}$ in 1997 during the growing season (May through October).

In both 1996 and 1997, as severity of Rhizoctonia foliar blight at R5 increased, the quantity of pods and seed and weight of harvested seed decreased (Figs. 2 and 3). This relationship was evident with both foliar and pod severity measurements, which suggests that yield loss to Rhizoctonia foliar blight is due primarily to loss of entire pods rather than from fewer seed per pod or smaller seed. These results are consistent with those of Joye et al. (16), who reported that both the weight and number of soybean seed per plant were reduced as incidence and severity of this disease increased in greenhouse studies. Fewer pods per plant, either because of reduced pod formation or loss of pods, has been described as the causal factor behind yield reductions associated with other diseases of soybean, including sudden death syndrome (Fusarium solani f. sp. glycines) (20), soybean dwarf (Soybean dwarf virus) (14), and bean pod mottle (Bean pod mottle virus) (11). The results of this study indicate that yield loss caused by Rhizoctonia foliar blight also is due to fewer pods per plant.

There was not a significant relationship between Rhizoctonia foliar blight severity at R5 and the proportion of partially filled pods or weight of 100 seed for either cultivar during both years. This suggests that surviving seed did not compensate for lost seed by increasing their weight, as has been noted in soybean plants damaged by southern green stink bugs (Nezara viridula) (22) or tobacco budworms (Heliothis virescens) (19). Incomplete pod filling has been identified as a factor contributing to soybean yield loss due to anthracnose (Colletotrichum spp.) (18). Smaller seed contribute to yield losses associated with diseases such as stem canker (Diaporthe phaseolorum var. meridionalis) (10) and sudden death syndrome $(17,20)$, and with defoliation by Mexican bean beetle (Epilachna varivestis) (21). Clearly, the mechanisms for yield loss due to Rhizoctonia foliar blight differ from those described for these diseases and insects.

The relationship between yield loss and disease severity at R5 was stronger when disease assessment was based on pods than on foliage (Figs. 2 and 3). When disease pressure was low (1997), yield effects could be predicted based on pod ratings but not always when foliar ratings were used. When disease pressure was high (1996), either foliar or pod ratings could be used to assess the impact of Rhizoctonia 


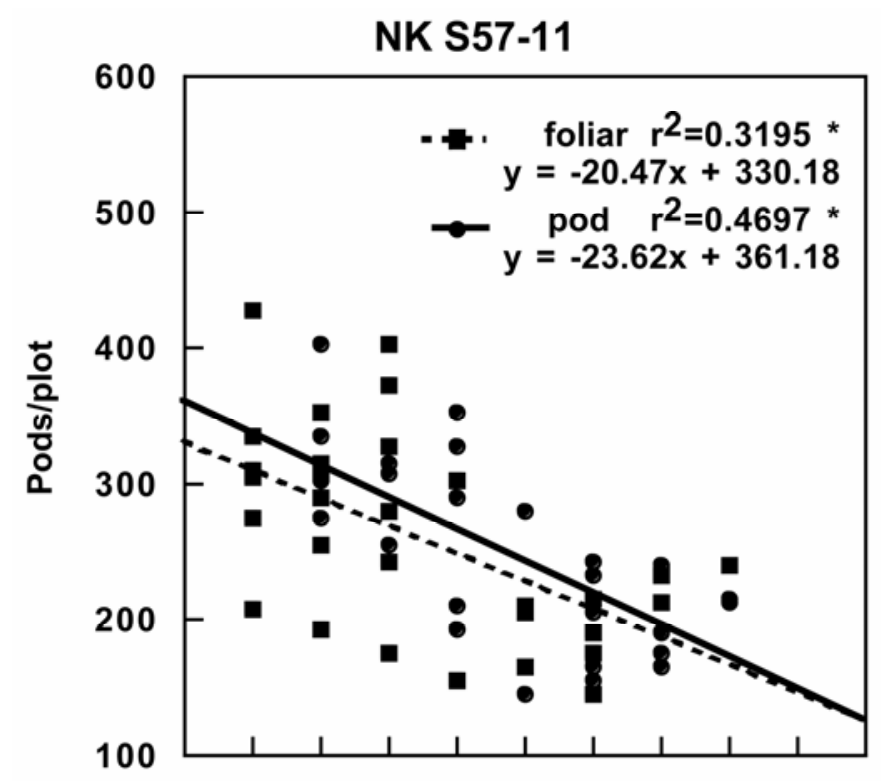

BUCKSHOT 723
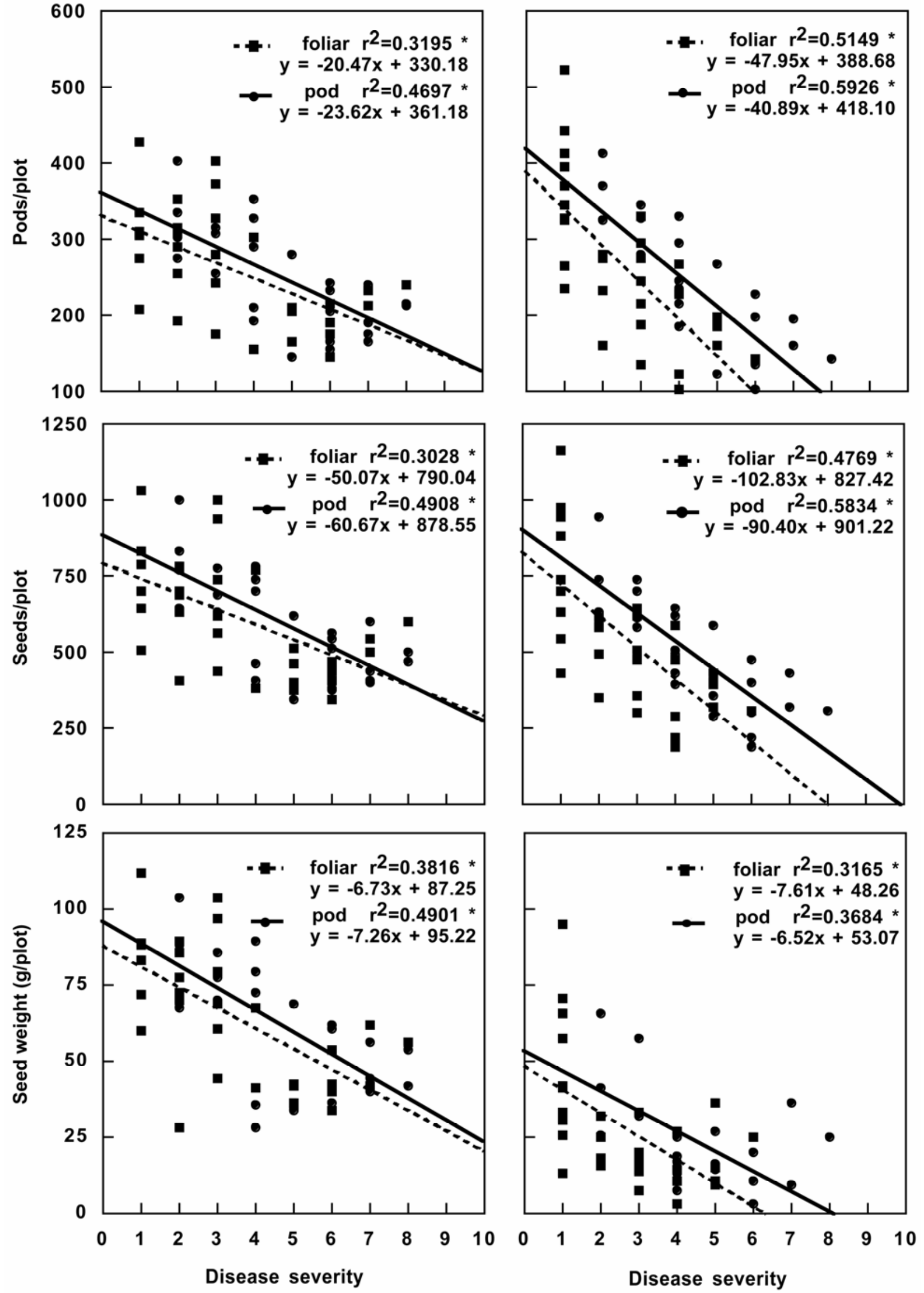

Fig. 2. Regression of Rhizoctonia foliar blight severity at R5 based on foliar or pod ratings to number of pods, number of seed, and weight of seed for soybean cvs. NK S57-11 and Buckshot 723 in 1996; $r^{2}$ values followed by an asterisk indicate significance at $P \leq 0.05$. 

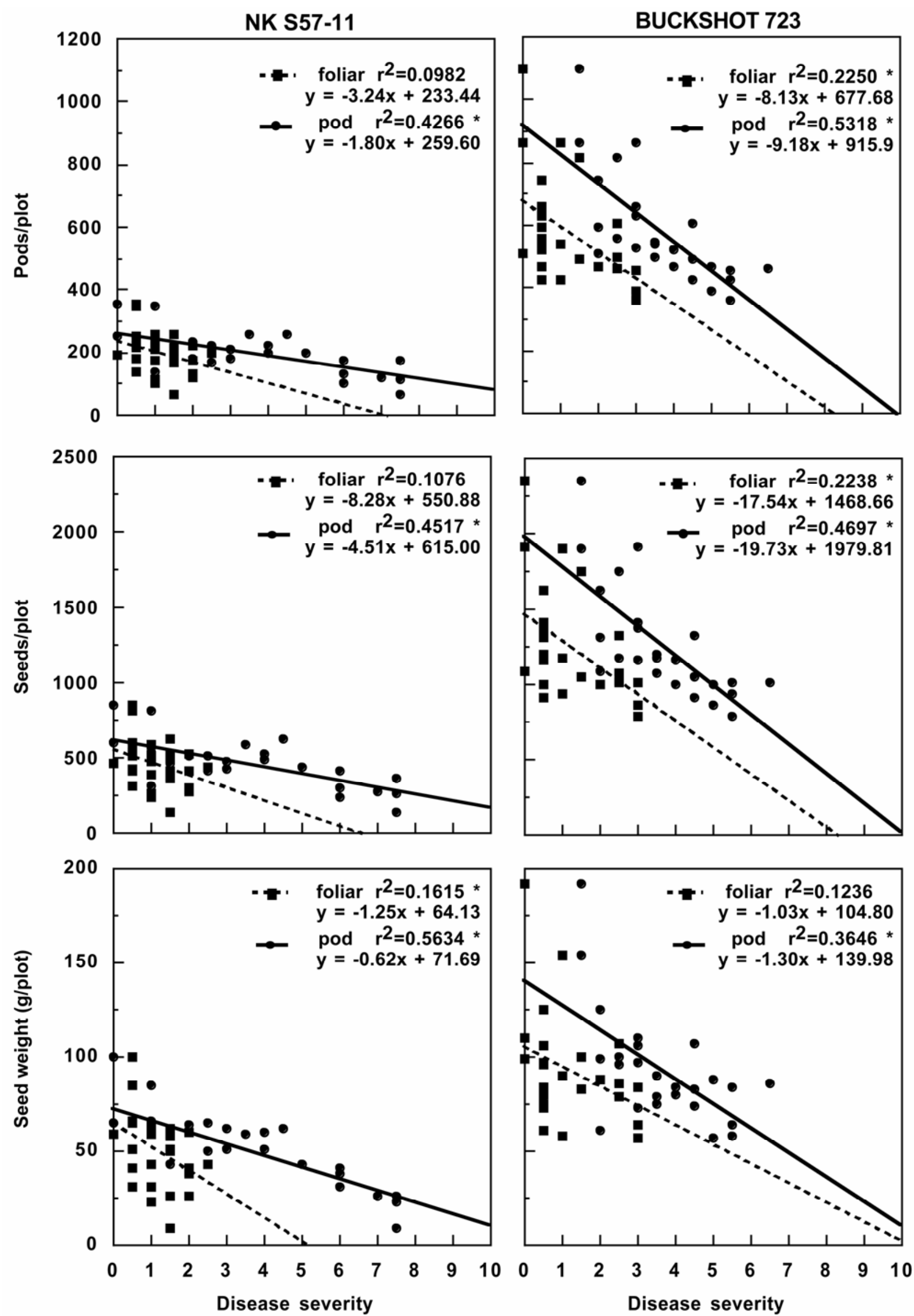

Fig. 3. Regression of Rhizoctonia foliar blight severity at R5 based on foliar or pod ratings to number of pods, number of seed, and weight of seed for soybean cvs. NK S57-11 and Buckshot 723 in 1997; $r^{2}$ values followed by an asterisk indicate significance at $P \leq 0.05$. 
foliar blight on yield. Typically, assessing cultivars for disease resistance occurs in high-disease environments. However, the results of this study suggest that information about relative levels of resistance to Rhizoctonia foliar blight can be obtained even in low-disease environments if pod ratings are used.

Differences between the moderately resistant and susceptible cultivars were evident based on both foliar and pod ratings in both years of the study. Yield loss estimates based on the number of pods or seed per plot were consistently greater on the susceptible cv. Buckshot 723, as indicated by larger regression coefficients in the regression equations (Figs. 2 and 3). However, yield loss estimates based on seed weight were not always greater on Buckshot 723. For pod assessments in 1996 and foliar assessments in 1997, larger regression coefficients were associated with moderately resistant cv. NK S57-11 for yield loss estimates based on seed weight.

Correlations between foliar and pod assessments of disease severity at R5 were consistent across the 2 years of the study. In 1996, when Rhizoctonia foliar blight was more severe, strong positive correlations were found between the two methods of disease severity assessment for moderately-resistant NK S57-11 $(r=0.8126, P<$ $0.0001)$, susceptible Buckshot 723 ( $r=$ $0.8782, P<0.0001)$, and across both cultivars $(r=0.8343, P<0.0001)$. In 1997 , when disease pressure was lower, positive correlations again were noted for NK S5711 ( $r=0.6540, P=0.0003)$, Buckshot 723 $(r=0.6954, P=0.0001)$, and across both cultivars $(r=0.5958, P<0.0001)$, though the correlations were markedly less strong.

It was generally observed that soybean plants with more severe disease tended to retain green stems and green pods longer than plots with little or no disease; however, specific data to support this observation were not recorded. Delayed maturity in soybean also has occurred in response to infection by Soybean dwarf virus (14) or Bean pod mottle virus $(1,11,24)$ and to injury by southern green stinkbug (6) or brown stink bug (Euschistus servus) (7). That these symptoms are associated with such a varied list of pests suggests that they all may act to disrupt the flow of photosynthates from their site of production (source) to the location where they are being actively utilized (sink) within the plant. Studies have documented that crop plants with reduced photosynthetic capacity due to defoliation $(2,5)$ or shading $(2,8)$ yield less than their counterparts grown under more optimal conditions. When plants are damaged by feeding insects or pathogens, the pests function as additional sinks, competing with the plant's own fruit and seed for photosynthetic products and altering plant growth $(15,26)$. Our observations suggest that $R$. solani also is capable of disrupting this source-sink relationship and delaying maturity, though its exact role in this process has yet to be experimentally determined.

In summary, results show that yield loss was due primarily to loss of entire pods. Because pods were determined to be the key factor in yield loss, pod-based disease assessments at the late R5 growth stage were better able to predict yield loss than were assessments based on soybean foliage at that time. Though either foliar or pod ratings could be used to estimate yield loss when disease pressure was high, pod ratings were the more reliable method under low-disease situations and did not require any additional time or effort than conducting foliar ratings. Based on these results, we suggest that pod ratings be used in assessing soybean reaction to Rhizoctonia foliar blight. Further research is needed to evaluate the role of Rhizoctonia foliar blight in delaying soybean maturity and in quantifying yield loss associated with this phenomenon.

\section{ACKNOWLEDGMENTS}

We thank R. J. Habetz for planting and maintaining research plots; and J. E. Kurle, A. Mengistu, and G. L. Sciumbato for manuscript review.

\section{LITERATURE CITED}

1. Abney, T. S., and Ploper, L. D. 1994. Effects of bean pod mottle virus on soybean seed maturation and seedborne Phomopsis spp. Plant Dis. 78:33-37.

2. Alkio, M., Schubert, A., Diepenbrock, W., and Grimm, E. 2003. Effect of source-sink ratio on seed set and filling in sunflower (Helianthus annuus L.). Plant Cell Environ. 26:1609-1619.

3. Atkins, J. G., Jr., and Lewis, W. D. 1954. Rhizoctonia aerial blight of soybean in Louisiana. Phytopathology 44:215-218.

4. Black, B. D., Russin, J. S., Griffin, J. L., and Snow, J. P. 1996. Herbicide effects on Rhizoctonia solani in vitro and Rhizoctonia foliar blight of soybean (Glycine max). Weed Sci. 44:711-716.

5. Board, J. E., and Harville, B. G. 1998. Lateplanted soybean yield response to reproductive source/sink stress. Crop Sci. 38:763-771.

6. Boethel, D. J., Russin, J. S., Weir, A. T., Layton, M. B., Mink, J. S., and Boyd, M. L. 2000. Delayed maturity associated with southern green stink bug (Heteroptera: Pentatomidae) injury at various soybean phenological stages. J. Econ. Entomol. 93:707-712.

7. Daugherty, D. M., Neustadt, M. H., Gehrke, C. W., Cavanah, L. E., Williams, L. F., and Green, D. E. 1964. An evaluation of damage to soybeans by brown and green stink bugs. J. Econ. Entomol. 57:719-722.

8. Egli, D. B., and Bruening, W. P. 2001. Sourcesink relationships, seed sucrose levels and seed growth rates in soybean. Ann. Bot. 88:235-242.

9. Fehr, W. R., Caviness, C. E., Burmood, D. T., and Pennington, J. D. 1971. Stages of development descriptions for soybeans, Glycine $\max ($ L.) Merr. Crop Sci. 11:25-26.

10. Fernandez, F. A., Phillips, D. V., Russin, J. S., and Rupe, J. C. 1999. Stem canker. Pages 3335 in: Compendium of Soybean Diseases, fourth edition. G. L. Hartman, J. B. Sinclair, and J. C. Rupe, eds. American Phytopathological Society Press, St. Paul, MN.

11. Gergerich, R. C. 1999. Bean pod mottle. Pages 61-62 in: Compendium of Soybean Diseases, fourth edition. G. L. Hartman, J. B. Sinclair, and J. C. Rupe, eds. American Phytopathological Society Press, St. Paul, MN.
12. Gomez, K. A., and Gomez, A. A. 1984. Statistical Procedures for Agricultural Research, second edition. John Wiley \& Sons, New York.

13. Harville, B. G., Russin, J. S., and Habetz, R. J. 1996. Rhizoctonia foliar blight reactions and seed yields in soybean. Crop Sci. 36:563-566.

14. Hewings, A. D., and Tolin, S. A. 1999. Soybean dwarf. Pages 64-65 in: Compendium of Soybean Diseases, fourth edition. G. L. Hartman, J. B Sinclair, and J. C. Rupe, eds. American Phytopathological Society Press, St. Paul, MN.

15. Hibberd, J. M., Quick, W. P., Press, M. C., and Scholes, J. D. 1998. Can source-sink relations explain responses of tobacco to infection by the root holoparasitic angiosperm Orobanche cernua? Plant Cell Environ. 21:333-340.

16. Joye, G. F., Berggren, G. T., and Berner, D. K. 1990. Effects of row spacing and within-row plant population on Rhizoctonia aerial blight of soybean and soybean yield. Plant Dis. 74:158-160.

17. Luo, Y., Hildebrand, K., Chong, S. K., Myers, O., and Russin, J. S. 2000. Soybean yield loss to sudden death syndrome in relation to symptom expression and root colonization by Fusarium solani f. sp. glycines. Plant Dis. 84:914-920.

18. Manandhar, J. B., and G. L. Hartman. 1999. Anthracnose. Pages 13-14 in: Compendium of Soybean Diseases, fourth edition. G. L. Hartman, J. B. Sinclair, and J. C. Rupe, eds American Phytopathological Society Press, St. Paul, MN.

19. McWilliams, J. M. 1984. Effects of tobacco budworm (Lepidoptera: Noctuidae) infestations on pod damage and yield loss in soybean. J. Econ. Entomol. 77:364-369.

20. Njiti, V. N., Shenaut, M. A., Suttner, R. J. Schmidt, M. E., and Gibson, P. T. 1998. Relationship between soybean sudden death syndrome disease measures and yield components in $\mathrm{F}_{6}$-derived lines. Crop Sci. 38:673-678.

21. Nolting, S. P., and Edwards, C. R. 1989. Yield response of soybeans to defoliation by the Mexican bean beetle (Coleoptera: Coccinelidae). J. Econ. Entomol. 82:1212-1218.

22. Russin, J. S., Layton, M. B, Orr, D. B., and Boethel, D. J. 1987. Within-plant distribution of, and partial compensation for, stink bug (Hemiptera:Pentatomidae) damage to soybean seeds. J. Econ. Entomol. 80:215-220.

23. Russin, J. S., and Stetina, S. R. 1999. Rhizoctonia foliar blight. Pages 24-25 in: Compendium of Soybean Diseases, 4th ed. G. L. Hartman, J. B. Sinclair, and J. C. Rupe, eds. American Phytopathological Society, St. Paul, MN.

24. Schwenk, F. W., and Nickell, C. D. 1980 Soybean green stem caused by bean pod mottle virus. Plant Dis. 64:863-865.

25. Stetina, K. C., and Russin, J. S. 1997. Estimating soybean yield loss caused by Rhizoctonia foliar blight. Page 23 in: Proc. South. Soybean Dis. Workers, Ft. Walton Beach, FL.

26. Watling, J. R., and Press, M. C. 1997. How is the relationship between the $\mathrm{C}_{4}$ cereal Sorghum bicolor and the $\mathrm{C}_{3}$ root hemi-parasites Striga hermonthica and Striga asiatica affected by elevated $\mathrm{CO}_{2}$ ? Plant Cell Environ. 20:1292-1300.

27. Whitam, K., Hollier, C.A., and Overstreet, C. 1997. 1997 Louisiana Plant Disease Control Guide. La Coop. Ext. Serv. Publ. 1802, Baton Rouge.

28. Wrather, J. A., Stienstra, W. C., and Koenning, S. R. 2001. Soybean disease loss estimates for the United States from 1996 to 1998. Can. J. Plant Pathol. 23:122-131.

29. Yang, X. B., Berggren, G. T., and Snow, J. P. 1990. Effects of free moisture and soybean growth stage on focus expansion of Rhizoctonia aerial blight. Phytopathology 80:497-503.

30. Yang, X. B., Snow, J. P., and Berggren, G. T. 1990. Analysis of epidemics of Rhizoctonia aerial blight in soybean in Louisiana. Phytopathology 80:386-392. 